value found by other authors. Contrary to our hypothesis, it was not modified by the amount of nitrogen.

Nitrogen percentage of the meal altered that of the stomachal chyme. During and after BN meal, this percentage was of 70-130 p. roo as compared to that of the diet.

During and after HN meal, digesta, chiefly the first ones, showed lower nitrogen percentage than that of the diet. This observation suggested that stomachal remains from the previous BN meal, diluted digesta from the HN meal offered is hours before. The share of these remains was calculated for each collect. Their sum gave an evaluation of total remains (2-26 p. 100) in the stomach at the beginning of the HN meal. Therefore, it did not depend on emptying by fistulation.

From litterature it can be supposed that these stomach remains would be different according to foods contained in the mixtures fed, and would be smaller when including treated starch.

\title{
TRANSIT ALIMENTAIRE CHEZ LE PORC EN CROISSANCE EFFET D'UN EXTRAIT DE FUMETERRE ET DE LA METTAPIMAZINE
}

\author{
L.-P. BORGIDA \\ Laboratoire de Recherches sur la Conservation et l'Efficacité des Aliments, \\ Centre national de Recherches zootechniques, I. N.R. A., \\ 78350 Jouy en Josas
}

Deux produits ont été choisis pour leur action relâchante sur les sphincters et les muscles lisses d'animaux de laboratoire, un nébulisat de fumeterre (Fumaria officinalis) à $75 \mathrm{mg} / \mathrm{kg}$ de poids vif chez le porc en croissance $(25-65 \mathrm{~kg})$, exp. I et la métapimazine, un dérivé de la phénothiazine, à $0,25 \mathrm{mg} / \mathrm{kg}$ de poids vif pour le porc durant la phase de finition (65-105 kg), exp. 2 .

Ces substances ont été ajoutées à des régimes finement broyés à base de tourteau de soja, maiss, cellulose en poudre et composé minéral vitaminisé équilibrés et distribués en pâtée à $28 \mathrm{p}$. Ioo MS. Le repas test, distribué le soir, 9 heures après le repas du matin, contient ro g de Polyéthylène glycol 4 ooo (PEG) et $\mathrm{I}, \mathrm{I}$ p. Ioo d'oxyde de chrome $\left(\mathrm{Cr}_{2} \mathrm{O}_{3}\right)$ absorbé sur de la cellulose selon la technique de Tisserand et al., (I962).

L'action de ces produits a été évaluée, soit par mesure de l'excrétion fécale des traceurs pendant 99 heures après un repas test (exp. I) sur 8 animaux, soit (exp. 2) par examen de la répartition de ces mêmes traceurs dans les divers segments du tube digestif de 12 animaux abattus 3 et 6 heures après le repas test.

On appelle, (d'après Castise et CASTLE., 1956) $\mathrm{T} x$ le temps après le repas test où $x$ p. roo du traceur est excrété, $T=T_{95}-T_{5}$ la durée du passage d'un traceur, son temps moyen de passage $\mathrm{R}$ est donné par la formule:

$$
\mathrm{R}=\frac{\mathrm{I}}{\mathrm{IO}} \sum_{i=0}^{9} \mathrm{~T}(5+\text { Io } i) .
$$

Les résultats préliminaires sont les suivants :

- Exp. I (tabl. I) : l'extrait de fumeterre ne modifie pas la durée de passage $(\Delta T) d u$ $\mathrm{Cr}_{2} \mathrm{O}_{3}$, il réduit celle du PEG de moitié. Le moment d'apparition des traceurs $\left(\mathrm{T}_{5}\right)$ est allongé et 


\section{TABLEAU I}

Influence du fumeterre sur le transit digestif:

paramètres des courbes d'excrétion cumulées des marqueurs (moyennes de 4 données)

Effect of fumeterre on the digestive transit :

parameters of the cumulated excretion curves of the tracers (means of 4 datas)

\begin{tabular}{|c|c|c|c|c|c|c|}
\hline Traceurs & Groupe & $T_{5}(\%)$ & $T_{95}(\%)$ & $\mathrm{T}$ & $\mathrm{R}$ & \\
\hline \multirow{2}{*}{$\mathrm{Cr}_{2} \mathrm{O}_{3}$} & Fumeterre & 31,0 & 72,2 & 41,2 & 50,1 & Fumeterre \\
\hline & Témoin & 23,5 & 64,5 & 41,0 & 39,3 & Control \\
\hline \multirow{2}{*}{ PEG } & Fumeterre & 25,5 & 48 & 22,5 & 43,9 & Fumeterre \\
\hline & Témoin & 22,5 & 67 & 44,5 & 36,8 & Control \\
\hline Tracers & group & & & & & \\
\hline
\end{tabular}

\section{TABLEAU 2}

Répartition relative des traceurs dans les différents segments du tube digestif, témoins (T) ou traités à la métapimazine (MP) (moyennes de 3 données)

Relative distribution of tracers in the different guts, control (C) or metapimazin submitted (MP) (means of 3 datas)

\begin{tabular}{|c|c|c|c|c|c|c|c|c|c|c|c|}
\hline \multirow{2}{*}{\multicolumn{2}{|c|}{$\begin{array}{c}\begin{array}{c}\text { Temps } \\
\text { après le repas }\end{array} \\
\text { Traceurs }\end{array}$}} & \multicolumn{4}{|c|}{$3 \mathrm{H}$} & \multicolumn{4}{|c|}{$6 \mathrm{H}$} & \multirow{2}{*}{\multicolumn{2}{|c|}{$\frac{\text { Time after meal }}{\text { Tracers }}$}} \\
\hline & & \multicolumn{2}{|c|}{ PEG } & \multicolumn{2}{|c|}{$\mathrm{Cr}_{2} \mathrm{O}_{3}$} & \multicolumn{2}{|c|}{ PEG } & \multicolumn{2}{|c|}{$\mathrm{Cr}_{2} \mathrm{O}_{3}$} & & \\
\hline $\begin{array}{l}\text { Niveau } \\
\text { du TD }\end{array}$ & groupe & $\mathrm{T}$ & MP & $\mathrm{T}$ & $\mathrm{MP}$ & $\mathrm{T}$ & MP & $\mathrm{T}$ & $\mathbf{M P}$ & Group & Gut \\
\hline \multicolumn{2}{|c|}{ Estomac } & 32,8 & 23,0 & 37,3 & 45,9 & 0 & 0 & 31,3 & 30,3 & \multicolumn{2}{|c|}{ Stomach } \\
\hline \multicolumn{2}{|c|}{ 1/3 duodénum } & 2,0 & 2,4 & 6,1 & 9,1 & 0,2 & 0,4 & 3,9 & 6,7 & \multicolumn{2}{|c|}{$1 / 3$ duodenum } \\
\hline \multicolumn{2}{|c|}{ 1/3 iléon 1} & 8,4 & 9,1 & 7,6 & 11,5 & 1,8 & 0,4 & & & \multicolumn{2}{|c|}{$1 / 3$ ileum 1} \\
\hline \multicolumn{2}{|c|}{$1 / 3$ iléon 2} & 29,1 & 33,1 & 17,9 & 23,7 & 4,5 & 6,1 & & & \multicolumn{2}{|c|}{$1 / 3$ ileum 2} \\
\hline \multicolumn{2}{|c|}{ Cæcum } & 15,3 & 2,4 & 3,9 & 8,5 & 34,1 & 29,0 & 13,6 & 16,1 & \multicolumn{2}{|c|}{ Caecum } \\
\hline \multicolumn{2}{|c|}{ Gros intestin } & 11,4 & 30,0 & 24,0 & 9,1 & 59,4 & 64,1 & 25,4 & 25,3 & \multicolumn{2}{|c|}{ Large gut } \\
\hline & & $C$ & $M P$ & $C$ & $M P$ & $C$ & $M P$ & $C$ & $M P$ & & \\
\hline
\end{tabular}


leur durée de rétention moyenne (R) s'accroît de $27 \mathrm{p}$. Ioo pour le $\mathrm{Cr}_{2} \mathrm{O}_{3}$ et de $19 \mathrm{P}$. Ioo pour le PEG. La dispersion des résultats est importante.

Les répercussions sur la croissance $(2 \times 6$ animaux $)$ ont été faibles $(+2 \mathrm{p}$. Ioo, NS) de même que l'indice de consommation $(-2 \mathrm{p}$. Ioo, NS) et sur la digestibilité de la matière organique $(+\mathrm{I}, 9$ point, NS).

- Exp. 2 (tabl. 2) : l'action de la métapimazine, 3 heures après le repas se manifeste par une tendance à l'accumulation de $\mathrm{Cr}_{2} \mathrm{O}_{3}$ dans l'estomac, l'intestin grêle et le cæcum accompagnée d'une vidange du PEG nettement accélérée dans ces deux réservoirs. Il en résulte une accumulation de ce PEG dans le gros intestin alors que $\mathrm{le} \mathrm{Cr}_{2} \mathrm{O}_{3}$ n'a pas encore atteint cet organe en grande quantité. Toutes ces différences (très significatives au niveau du cæcum et du gros intestin) disparaissent 6 heures après le repas.

Seuls les résultats d'excrétion fécale des traceurs obtenus avec la métapimazine (analyses en cours) nous permettront de comparer les modes d'actions des deux produits essayés, mais d'ores et déjà, on peut supposer une grande similitude des mécanismes mis en cause.

L'accélération du transit du PEG observée dans l'expérience I est en bon accord avec la vidange accélérée de la phase aqueuse des divers segments du tube digestif de l'essai $n^{0} 2$, ce qui suggère un relâchement des sphincters sous l'effet des deux substances ajoutées.

Le délai d'excrétion de la matière sèche, marquée au $\mathrm{Cr}_{2} \mathrm{O}_{3}$, est en relation avec l'accumulation de ce traceur dans les premiers compartiments digestifs pendant les 3 premières heures de la digestion. On peut donc penser à un effet d'inhibition de la motricité gastrointestinale marqué dans les premières heures après le repas, et s'annulant ensuite puisque après 6 heures et durant l'excrétion fécale du $\mathrm{Cr}_{2} \mathrm{O}_{3}$, on ne constate plus aucun effet.

Il semble donc que des modifications du transit induites par des actions pharmacodynamiques n'ont qu'un effet limité sur l'efficacité de ce dernier. Il pourrait en être différemment si, sous l'effet de traitements physico-chimiques, par exemple, le régime contenait des constituants solubles en proportion variable dont la digestion rapide pourrait permettre des effets d'interaction intéressants au plan métabolique.

\section{RÉFÉRENCES BIBLIOGRAPHIQUES}

Castle E.-J., Castle M.-E., 1956. J. Agric. Sci., 47, 196-203.

Tisserand J.-L., Coleou J., Zelter S.-Z., 1962. C. R. Acad. Sci. Paris, 254, 2233-2235.

\section{SUMMARY}

\section{PASSAGE OF FOOD IN GROWING PIGS.} EFFECT OF A " FUMETERRE 》 EXTRACT AND OF METAPIMAZINE

Two substances were selected for their releasing action on sphincters and smooth muscles in the laboratory animal :

- a fumeterre (Fumaria officinalis) spray used at a dose of $75 \mathrm{mg} / \mathrm{kg}$ live weight in growing pigs $(25-65 \mathrm{~kg})$, exp. no I ;

- metapimazine, a phenothiazine derivate, used at a dose of $0.25 \mathrm{mg} / \mathrm{kg}$ live weight in the finishing pigs $\left(65^{-105} \mathrm{~kg}\right)$, exp. no 2 .

These substances were added to a finsly ground diet containing balanced proportions of maize, powdered crude fiber, soyabean oil-meal, with minerals and vitamins, offered as a soup with 
28 p. Ioo DM. A test meal, given in the evening, 9 hours after the morning meal, contained ro $g$ polyethylene glycol (PEG) and $\mathrm{I} . \mathrm{I}$ chromium oxyde $\left(\mathrm{Cr}_{2} \mathrm{O}_{3}\right)$ adsorbed on cellulose following TISSERAND technique (1962).

The activity of these substances was evaluated either by measurement of the faecal excretion of tracers during 99 hours after the test meal (exp. I) or (exp. 2) by examination of the distribution of tracers in the gut of $\mathrm{I} 2$ animals slaughtered 3 or 6 hours after the test meal.

According to CASTLE and CASTLE. (1956) we call $\mathrm{T} x$ the time after the test meal when $x$ p. I00 of a tracers is excreted, $\mathrm{T}=\mathrm{T}_{95}-\mathrm{T}_{5}$ its time of passage and its mean time of passage $\mathrm{R}$ is given by the formula :

$$
\mathrm{R}=\frac{\mathrm{I}}{\mathrm{IO}} \sum_{i=0}^{9} \mathrm{~T}(5+\text { Io } i)
$$

Preliminary results are the following :

- Exp. I (table $\mathrm{I}$ ) : the fumeterre spray did not modify the $\mathrm{Cr}_{3} \mathrm{O}_{3}$ passage duration $(\triangle T$ ), it reduced by half that of the PEG.

The moment $\left(\mathrm{T}_{06}\right)$ when tracer appeared in faeces was delayed and mean retention time (R) increased by 27 p. Ioo for $\mathrm{Cr}_{2} \mathrm{O}_{3}$ and I9 p. Ioo for PEG. The scattering of results was rather wide.

Effects upon growth $(2 \times 6$ animals $)$ were slight $(+2$ p. roo, NS $)$ as were those on food conversion ( -2 p. Ioo, NS) and organic matter digestibility (+ I.9 point, NS).

- Exp. 2 : metapimazine effect, 3 hours after the meal, was characterized by a trend for $\mathrm{Cr}_{2} \mathrm{O}_{3}$ accumulation in the stomach, small intestine and caecum with a faster emptying of PEG in these two reservoirs. This is the reason why PEG increased in the large gut when $\mathrm{Cr}_{2} \mathrm{O}_{3}$ had not yet reached this organ. All these particularities very significant in the caecum and large gut, disappeared 6 hours after the meal.

Only data on faecal excretion of tracers obtained with metapimazine (trial in progress) will make possible comparison of the action patterns of the substances used. However, it is already possible to forsee that the mechanisms involved are similar. The faster passage of PEG observed in exp. $I$ is in good agreement with the accelerated gut emptying in exp. 2, suggesting a sphincter release because of the added substances.

The delay in the excretion of the $\mathrm{Cr}_{2} \mathrm{O}_{3}$ marked dry matter is also to be related to this tracer accumulation in the first digestive compartment during the early 3 hours of digestion.

This leads to suppose an inhibitory effect on the gastrointestinal motility, pronounced in the first hours after the meal then reduced to zero, since 6 hours later and during the faecal excretion of $\mathrm{Cr}_{2} \mathrm{O}_{3}$, no effect was observed.

So, modifications of the passage time by drug action is of little significance for efficiency of food in the pig. This might be quite different when processing food of high soluble matter content, the faster digestion of which would allow interesting metabolic interactions. 